\title{
Fatal hepatic decompensation in a patient with hepatitis $B$ cirrhosis following famciclovir withdrawal
}

Robert P Myers $\mathrm{MD}^{1}$, Rabindra Chaudhary $\mathrm{PhD}^{2}$, Kevin Fonseca $\mathrm{PhD}^{3}$, Samuel S Lee MD ${ }^{1}$

\begin{abstract}
RP Myers, R Chaudhary, K Fonseca, SS Lee. Fatal hepatic decompensation in a patient with hepatitis $\mathrm{B}$ cirrhosis following famciclovir withdrawal. Can J Gastroenterol 2000;14(8):725727. Hepatitis B virus (HBV) infection is a major cause of chronic liver disease worldwide. Famciclovir is a nucleoside analogue with potent antiviral activity that appears promising in the management of patients with HBV infection. No data exist regarding the safety of nucleoside analogue withdrawal in patients treated for HBV cirrhosis. The authors describe a 41-year-old man with compensated HBV cirrhosis who developed fatal hepatic decompensation due to a rebound in viral replication within six weeks of discontinuing famciclovir therapy. Although several mutations in the HBV DNA polymerase gene have been documented, none has been associated with famciclovir resistance or adverse clinical outcomes. Clinicians should consider the risk of inducing serious flares in hepatic inflammation as a result of abrupt nucleoside analogue withdrawal. Until further data are available regarding the safety of withdrawal of these agents, indefinite treatment may be required in patients with established cirrhosis.
\end{abstract}

Key Words: Adverse effects; Amino acid sequence; 2-Aminopurine analogues and derivatives; Antiviral agents; DNA-directed DNA polymerase; Famciclovir; Hepatitis B virus; Lamivudine; Mutation

\section{Décompensation hépatique fatale chez un patient atteint de cirrhose liée à l'hépatite $B$ après l'arrêt du famciclovir}

RÉSUMÉ : Le virus de l'hépatite B (HBV) est une importante cause de maladie hépatique chronique dans le monde. Le famciclovir est un analogue nucléosidique qui exerce une puissante activité antivirale et semble prometteur pour le traitement des patients infecté par le HBV. On ne dispose d'aucune donnée sur l'innocuité des analogues nucléosidiques lorsqu'ils sont cessés chez des patients traités pour une cirrhose liée au HBV. Les auteurs décrivent ici le cas d'un homme de 41 ans souffrant d'une cirrhose liée au HBV compensée qui a développé une décompensation hépatique fatale due à une réplication virale de rebond dans les six semaines qui ont suivi l'arrêt de son traitement au famciclovir. Bien que plusieurs mutations du gène de la polymérase de l'ADN du HBV ait été documentées, aucune n'a été associée à la résistance au famciclovir ou à une évolution clinique défavorable. Les médecins doivent tenir compte du risque d'induire de graves poussées d'exacerbation de l'inflammation hépatique par suite de l'arrêt brusque du traitement aux analogues nucléosidiques. Tant qu'on ne disposera pas de données plus abondantes au sujet des conséquences de l'arrêt de ces agents, il faudra peut-être administrer un traitement ininterrompu aux patients souffrant d'une cirrhose avérée.
$\mathrm{H}$ epatitis $B$ virus (HBV) infection is a major cause of chronic hepatitis, cirrhosis and hepatocellular carcinoma (1). The nucleoside analogues lamivudine and famciclovir have emerged as promising agents in the management of chronic HBV infection (2,3). By inhibiting HBV DNA polymerase, these agents have proved effective in reducing
HBV replication. Furthermore, hepatitis $B$ e antigen $\left(\mathrm{HB}_{\mathrm{e}} \mathrm{Ag}\right)$ seroconversion, normalization of liver enzyme concentrations and improvement in liver histology are seen in many patients $(4,5)$. Lamivudine and famciclovir may be effective in the prevention and treatment of recurrent HBV infection after liver transplantation $(6,7)$.

This article was a winning case submission from "Consults in Gastroenterology: A Case Study Competition for Fellows and Residents in Gastroenterology"

${ }^{1}$ Division of Gastroenterology and Hepatology and ${ }^{3}$ Department of Microbiology and Infectious Diseases, University of Calgary, Calgary, Alberta;

${ }^{2}$ Diagnostic Virology Division, Laboratory Centre for Disease Control, Winnipeg, Manitoba

Correspondence: Dr Robert P Myers, Area 5B, University of Calgary Medical Clinic, 3330 Hospital Drive Northwest, Calgary, Alberta

T2N 4T3. Telephone 403-220-8457, fax 403-270-0995, e-mail drrobpmyers@hotmail.com

Received for publication July 4, 2000. Accepted July 4, 2000 


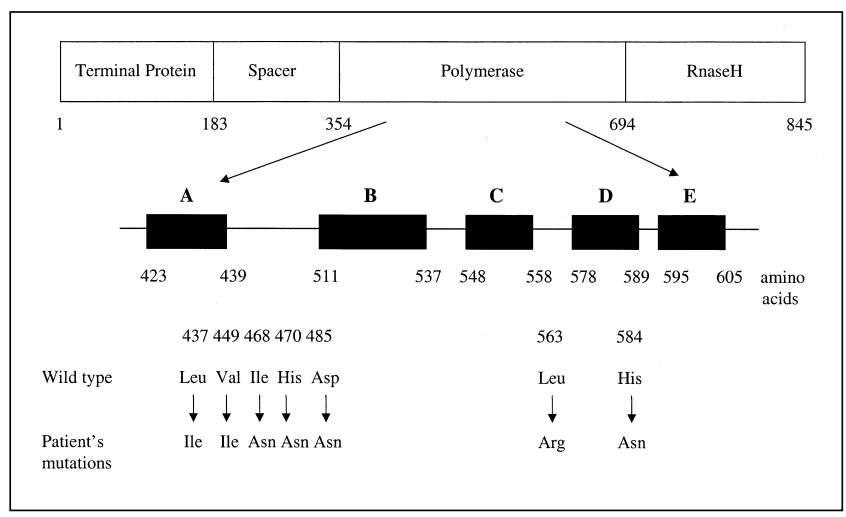

Figure 1) Structural organization of the hepatitis B virus DNA polymerase, wild-type amino acid sequence and mutations identified in the case patient. Arg Arginine; Asn Asparagine; Asp Aspartate; Gln Glutamine; His Histidine; Ile Isoleucine; Leu Leucine; Val Valine.

An important question remains, however, concerning the role of nucleoside analogues in the treatment of patients with $\mathrm{HBV}$ cirrhosis. Is lifelong therapy required or can these agents be stopped safely without risking serious flares in hepatic inflammation? Follow-up data of patients treated transiently with these agents are not available. Thus far, no serious sequelae of discontinuing the nucleoside analogues have been reported. We describe the first reported case of fatal hepatic decompensation in a patient with compensated HBV cirrhosis due to a rebound in viral replication shortly after the discontinuation of famciclovir.

\section{CASE PRESENTATION}

A 41-year-old white man was evaluated in April 1993 for sexually acquired HBV infection diagnosed in 1985 . The patient denied any symptoms of liver disease as well as alcohol consumption, hepatotoxin exposure and use of medications. On examination, the patient was anicteric. The liver was not enlarged, but the spleen was palpable $2 \mathrm{~cm}$ below the left costal margin. He had numerous spider angiomata, but the remainder of the examination was unremarkable. Laboratory investigations revealed thrombocytopenia $\left(130 \times 10^{9}\right.$ platelets/L) but normal hemoglobin and white blood cell counts. Liver enzyme concentrations were mildly elevated (alanine aminotransferase [ALT] $140 \mathrm{U} / \mathrm{L}$ [normal 7 to $56 \mathrm{U} / \mathrm{L}$ ]; alkaline phosphatase $187 \mathrm{U} / \mathrm{L}$ [normal 30 to $115 \mathrm{U} / \mathrm{L}$ ]), but the bilirubin, albumin and coagulation profiles were normal. Serological testing revealed that the patient was positive for $\mathrm{HB}_{\mathrm{e}} \mathrm{Ag}$, but negative for antihepatitis $\mathrm{Be}$, antihepatitis $\mathrm{C}$ virus and antihuman immunodeficiency virus-1 antibodies. Ultrasonography confirmed splenomegaly, but the liver was sonographically normal. A percutaneous liver biopsy specimen showed chronic active hepatitis and cirrhosis.

In August 1994, the patient began taking interferon $10^{6} \mathrm{U}$ three times per week. Before starting treatment, he tested positive for HBV DNA. During and after 16 weeks of therapy, his ALT concentration remained 1.5 to 2.5 times the upper limit of normal, and he persistently tested positive for $\mathrm{HB}_{\mathrm{e}} \mathrm{Ag}$.
The patient was then monitored for three years without receiving therapy for $\mathrm{HBV}$ infection. He remained positive for $\mathrm{HB}_{\mathrm{e}} \mathrm{Ag}$ during the majority of this interval, but the patient was asymptomatic (Child-Pugh class A). In October 1997, the ALT concentration was $341 \mathrm{U} / \mathrm{L}$, and the HBV DNA concentration was $86 \mathrm{pg} / \mathrm{mL}$ (Abbott hybridization assay). The patient was then started on famciclovir $500 \mathrm{mg}$ tid in mid-November. Three weeks after starting therapy, the patient's HBV DNA concentration had decreased to $9.4 \mathrm{pg} / \mathrm{mL}$, but he remained $\mathrm{HB}_{\mathrm{e}} \mathrm{Ag}$ positive. The ALT concentration also decreased to $191 \mathrm{U} / \mathrm{L}$. Six months later, the famciclovir was discontinued because of persistent $\mathrm{HB}_{\mathrm{e}} \mathrm{Ag}$ positivity. The patient remained asymptomatic, and the examination was unchanged.

Five weeks after stopping treatment, the patient was reassessed. Shortly after discontinuing famciclovir, he noticed increasing jaundice, fatigue and testicular swelling. On examination, the patient was jaundiced and had a right hydrocele. The remainder of the examination was unchanged. Laboratory investigations revealed an ALT concentration of $208 \mathrm{U} / \mathrm{L}$, a bilirubin concentration of $38 \mu \mathrm{mol} / \mathrm{L}$, an international normalized ratio (INR) of 2.6 and an albumin concentration of $30 \mathrm{~g} / \mathrm{L}$. He remained $\mathrm{HB}_{\mathrm{e}} \mathrm{Ag}$ positive and anti$\mathrm{HB}_{\mathrm{e}}$ negative. The HBV DNA concentration had increased dramatically to $533 \mathrm{pg} / \mathrm{mL}$. Because there was evidence of hepatic decompensation thought to be secondary to increased viral replication, the patient was started on lamivudine $150 \mathrm{mg} /$ day.

Five days later, the patient was hospitalized with increasing jaundice, ascites and diffuse abdominal discomfort. He had no fever or history of gastrointestinal hemorrhage. Physical examination revealed marked jaundice, tense ascites, edema, splenomegaly and asterixis. The ALT and bilirubin concentrations had risen to $710 \mathrm{U} / \mathrm{L}$ and $402 \mu \mathrm{mol} / \mathrm{L}$, respectively. The albumin concentration was $22 \mathrm{~g} / \mathrm{L}$, glucose concentration $2.6 \mathrm{mmol} / \mathrm{L}$ and INR 3.6. He was positive for $\mathrm{HB}_{\mathrm{e}} \mathrm{Ag}$ but negative for HBV DNA. The patient was treated with diuretics and lactulose, as well as ceftriaxone empirically for spontaneous bacterial peritonitis. Famciclovir $500 \mathrm{mg}$ tid was reintroduced. The patient was discharged two weeks later after gradual symptomatic improvement. On discharge, the ALT concentration had fallen to $190 \mathrm{U} / \mathrm{L}$, but the bilirubin concentration had risen to $565 \mu \mathrm{mol} / \mathrm{L}$.

Six days later, the patient was readmitted for management of an upper gastrointestinal hemorrhage and hepatic encephalopathy. Urgent gastroscopy and band ligation were performed for bleeding esophageal varices. Laboratory investigations revealed an ALT concentration of $182 \mathrm{U} / \mathrm{L}$, a bilirubin concentration of $550 \mu \mathrm{mol} / \mathrm{L}$, an albumin concentration of $18 \mathrm{~g} / \mathrm{L}$ and an INR of 2.8. The patient was not considered a candidate for liver transplantation because his most recent available HBV DNA test was positive, which is a contraindication to liver transplantation. The patient died 12 days later as a result of progressive hepatic and renal failure complicated by pulmonary edema refractory to medical management.

The HBV DNA polymerase gene from a blood sample 
collected six days before the patient's death was sequenced using standard methods (8). Several mutations in the amino acid sequence of the polymerase were found (Figure 1).

\section{DISCUSSION}

The nucleoside analogues lamivudine and famciclovir are promising alternatives to interferon in the management of patients with chronic HBV infection $(3,4)$. Although thousands of patients have been treated with these agents, the safety of their withdrawal in patients with compensated cirrhosis has yet to be reported. As illustrated by this case, discontinuation of nucleoside analogue therapy in patients with significant $\mathrm{HBV}$-related liver disease can result in serious flares of hepatic inflammation.

In this case, we believe that there was a causal relationship between the withdrawal of famciclovir therapy and the patient's fatal decompensation. Perhaps most striking is the temporal relationship between famciclovir discontinuation and the patient's clinical deterioration; within six weeks of stopping famciclovir, the patient presented with severe hepatitis. Although known to have cirrhosis on liver biopsy five years previously, the patient had no prior evidence of decompensation. The dramatic increase in HBV DNA concentration ( 9.4 to $533 \mathrm{pg} / \mathrm{mL}$ ) lends further support to the hypothesis that famciclovir withdrawal led to a rebound in viral replication and ultimately the patient's demise.

An alternative but less likely explanation for the patient's deterioration is that a famciclovir-resistant mutant devel-

\section{REFERENCES}

1. Lee WM. Hepatitis B virus infection. N Engl J Med 1997;337:1733-45.

2. Dienstag JL, Perillo RP, Schiff ER, Bartholomew M, Vicary C, Rubin M. A preliminary trial of lamivudine for chronic hepatitis B infection. N Engl J Med 1995;333:1657-61.

3. Main J, Brown J, Howells C, et al. A double blind, placebo-controlled study to assess the effect of famciclovir on virus replication in patients with chronic hepatitis B virus infection. J Viral Hepatitis 1996;3:211-5.

4. Lai CL, Chien RN, Leung NWY, et al. A one-year trial of lamivudine for chronic hepatitis B. N Engl J Med 1998;339:61-8.

5. Trépo C, Jezek P, Atkinson G, Boon R. Efficacy of famciclovir in chronic hepatitis B: results of a dose finding study. Hepatology 1996;24(Suppl):188A. (Abst)

6. Perillo R, Rakela J, Martin P, et al. Lamivudine for suppression and/or prevention of hepatitis $\mathrm{B}$ when given pre/post liver transplantation (OLT). Hepatology 1997;26(Suppl):315A. (Abst)

7. Rayes N, Seehofer D, Bechstein WO, et al. Long-term results of famciclovir for recurrent or de novo hepatitis B virus infection after liver transplantation. Clin Transplant 1999;13:447-52.

8. Pichoud C, Seignères B, Wang A, Trépo C, Zoulim F. Transient selection of a hepatitis $B$ virus polymerase gene mutant with a oped, permitting uncontrolled viral replication. Numerous studies have documented the emergence of drug-resistant HBV strains during monotherapy with nucleoside analogues $(9,10)$. During 12 months of lamivudine treatment, approximately $14 \%$ of patients develop mutations in the YMDD motif of the viral polymerase (4). In an analogous fashion, several mutations in the polymerase have been identified in patients displaying breakthrough viremia during famciclovir therapy $(11,12)$. In our patient, several mutations were identified, but none has been implicated in the development of famciclovir resistance or adverse clinical events.

Some authors have expressed concern that the emergence of drug-resistant mutants in patients treated with nucleoside analogues may preclude individuals from liver transplantation (13). This is an important consideration, particularly in Canada, where negative serum HBV DNA is a prerequisite for transplantation. As illustrated by this case, the withdrawal of drug therapy due to fear of these mutants may have disastrous clinical consequences for a patient with established cirrhosis.

The patient described in this case developed fatal hepatic decompensation due to a rebound in viral replication shortly after the discontinuation of famciclovir therapy. Although additional data regarding the safety of nucleoside analogue withdrawal in patients with compensated HBV cirrhosis are required to confirm our findings, we suggest that indefinite treatment may be required in patients with borderline hepatic reserve.

decreased replication capacity and famciclovir resistance. Hepatology 1999;29:230-7.

9. Ling R, Mutimer D, Ahmed M, et al. Selection of mutations in the hepatitis $\mathrm{B}$ virus polymerase during therapy of transplant recipients with lamivudine. Hepatology 1996;24:711-3.

10. Tillmann HL, Trautwein C, Bock T, et al. Mutational pattern of hepatitis $B$ virus on sequential therapy with famciclovir and lamivudine in patients with hepatitis $\mathrm{B}$ virus reinfection occurring under HBIg immunoglobulin after liver transplantation. Hepatology 1999;30:244-56.

11. Aye TT, Bartholomeusz AI, Shaw T, et al. Hepatitis B virus polymerase mutations during famciclovir therapy in patients following liver transplantation. Hepatology 1996;24(Suppl):285A. (Abst)

12. Xiong X, Yang H, Westland CE, Zou R, Gibbs CS. In vitro evaluation of hepatitis $\mathrm{B}$ virus polymerase mutations associated with famciclovir resistance. Hepatology 2000;31:219-24.

13. Villeneuve JP, Condreay LD, Willems B, et al. Lamivudine treatment for decompensated cirrhosis resulting from chronic hepatitis $B$. Hepatology 2000;31:207-10. 


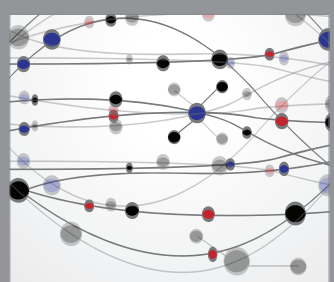

The Scientific World Journal
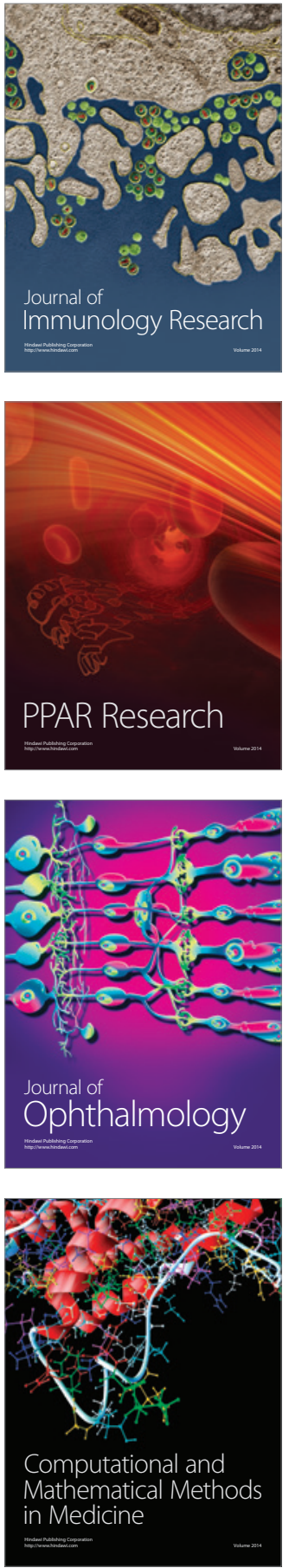

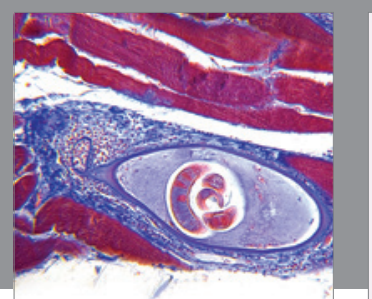

Gastroenterology Research and Practice

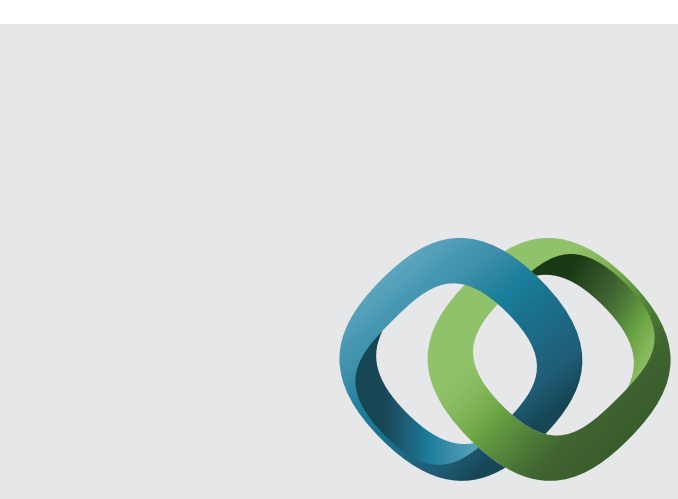

\section{Hindawi}

Submit your manuscripts at

http://www.hindawi.com
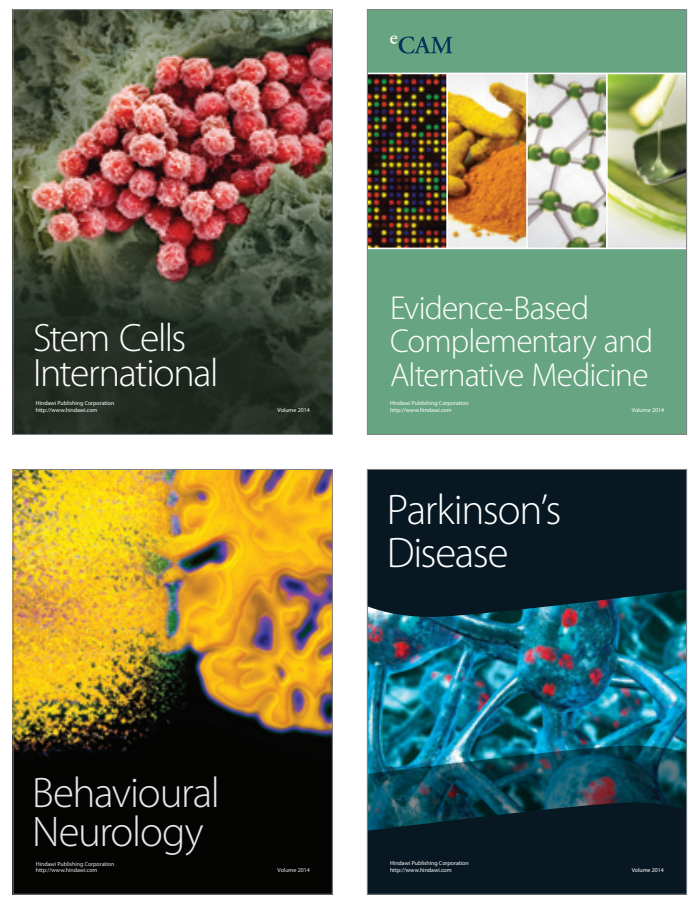
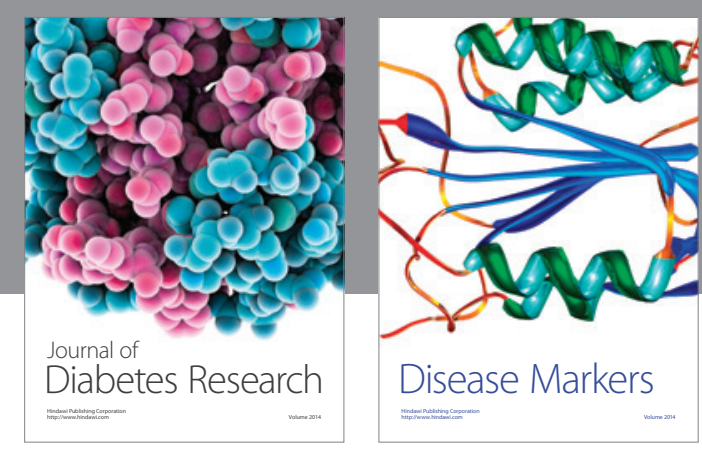

Disease Markers
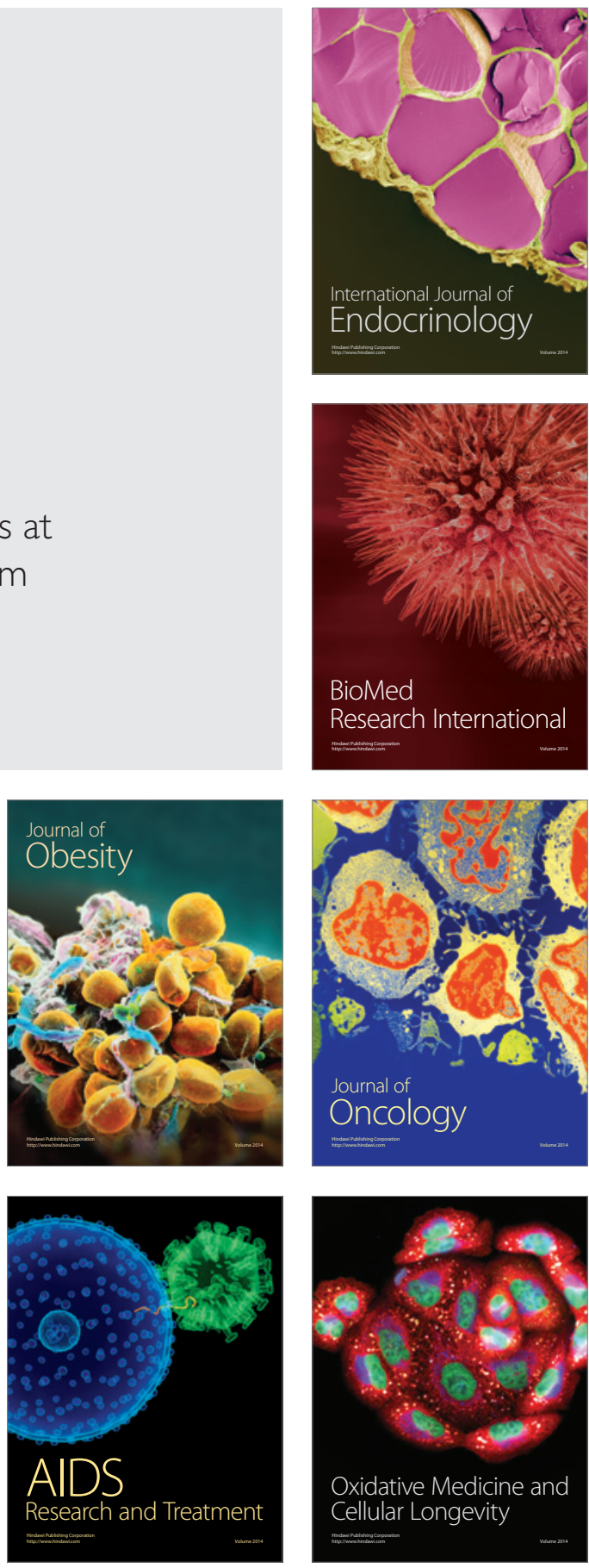